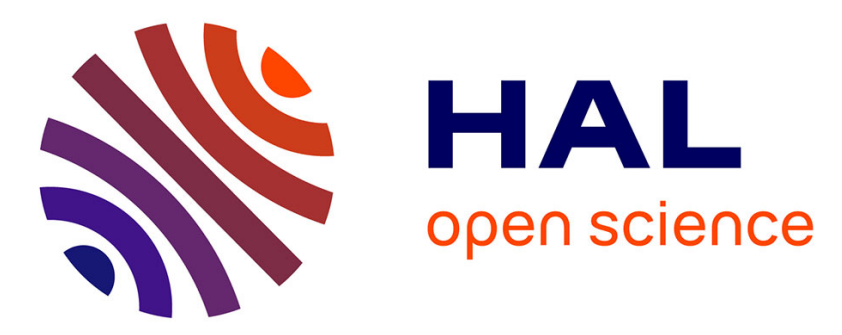

\title{
Is TRPV-1 a useful target in respiratory diseases?
}

Masaya Takemura, David Quarcoo, Akio Niimi, Q. Thai Dinh, Pierangelo

Geppetti, Axel Fischer, K. Fan Chung, David A. Groneberg

\section{To cite this version:}

Masaya Takemura, David Quarcoo, Akio Niimi, Q. Thai Dinh, Pierangelo Geppetti, et al.. Is TRPV1 a useful target in respiratory diseases?. Pulmonary Pharmacology \& Therapeutics, 2008, 21 (6), pp.833. 10.1016/j.pupt.2008.09.005 . hal-00499162

\section{HAL Id: hal-00499162 \\ https://hal.science/hal-00499162}

Submitted on 9 Jul 2010

HAL is a multi-disciplinary open access archive for the deposit and dissemination of scientific research documents, whether they are published or not. The documents may come from teaching and research institutions in France or abroad, or from public or private research centers.
L'archive ouverte pluridisciplinaire HAL, est destinée au dépôt et à la diffusion de documents scientifiques de niveau recherche, publiés ou non, émanant des établissements d'enseignement et de recherche français ou étrangers, des laboratoires publics ou privés. 


\section{Author's Accepted Manuscript}

Is TRPV-1 a useful target in respiratory diseases?

Masaya Takemura, David Quarcoo, Akio Niimi, Q. Thai Dinh, Pierangelo Geppetti, Axel Fischer, K. Fan Chung, David A. Groneberg

PII: $\quad$ S1094-5539(08)00093-X

DOI: $\quad$ doi:10.1016/j.pupt.2008.09.005

Reference: $\quad$ YPUPT 861

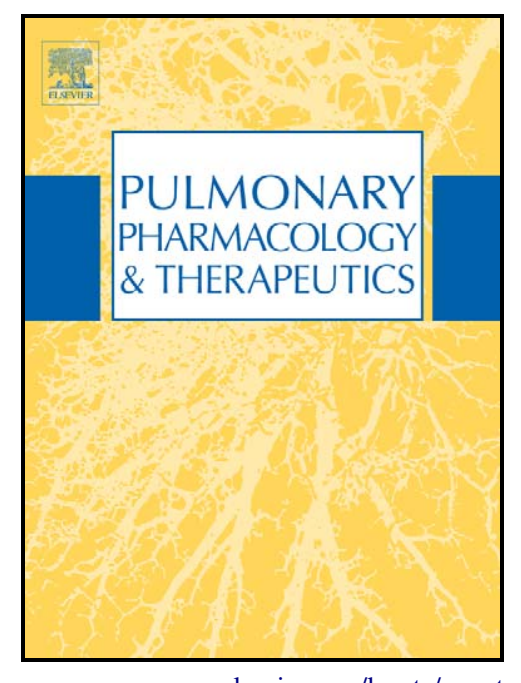

www.elsevier.com/locate/ypupt

To appear in: Pulmonary Pharmacology \& Therapeutics

Received date: 28 July 2008

Revised date: 15 September 2008

Accepted date: 24 September 2008

Cite this article as: Masaya Takemura, David Quarcoo, Akio Niimi, Q. Thai Dinh, Pierangelo Geppetti, Axel Fischer, K. Fan Chung and David A. Groneberg, Is TRPV-1 a useful target in respiratory diseases?, Pulmonary Pharmacology \& Therapeutics (2008), doi:10.1016/j.pupt.2008.09.005

This is a PDF file of an unedited manuscript that has been accepted for publication. As a service to our customers we are providing this early version of the manuscript. The manuscript will undergo copyediting, typesetting, and review of the resulting galley proof before it is published in its final citable form. Please note that during the production process errors may be discovered which could affect the content, and all legal disclaimers that apply to the journal pertain. 
Type of contribution: Review manuscript (Revised manuscript: PPT 08-98)

Date of preparation: Sep 15, 2008

Number of text pages: 30 , tables: 0, figures: 1

\section{Title: Is TRPV-1 a useful target in respiratory diseases?}

Masaya Takemura ${ }^{1^{*}}$, David Quarcoo ${ }^{1}$, Akio Niimi $^{2}$, Q. Thai Dinh ${ }^{3}$,

Pierangelo Geppetti ${ }^{4}$, Axel Fischer ${ }^{1,3}$, K. Fan Chung ${ }^{5}$, David A. Groneberg ${ }^{1}$

1 Institute of Occupational Medicine, Charité - Universitätsmedizin Berlin, Free University Berlin and Humboldt-University Berlin, D-14195 Berlin, Germany

2 Department of Respiratory Medicine, Kyoto University, 606-8507 Kyoto, Japan

3 Otto-Heubner-Centre, Pneumology and Immunology, Charité Universitätsmedizin Berlin, Free University Berlin and Humboldt-University Berlin, D-13353 Berlin, Germany

4 Department of Surgery and Intensive Care, Division of Pharmacology, University of Florence, 50139 Florence, Italy

$5 \quad$ National Heart \& Lung Institute, Imperial College London and Royal Brompton \& Harefield NHS Trust, SW3 6LY London, UK

* Corresponding author:

Masaya Takemura

Charité - Universitätsmedizin Berlin

Institute of Occupational Medicine

Thielallee 69-73 D-14195 Berlin, Germany

Tel: $\quad$ +49-30- 450 529559, Fax: +49-30-450 529952

Email:masaya.takemura@charite.de 


\begin{abstract}
This review focuses on the transient receptor potential vanilloid 1 (TRPV1). TRPV1 is a non-selective cation channel predominantly expressed in the cell membranes of sensory afferent fibers, which are activated multi-modally. In the mammalian respiratory system, immunohistochemical and electrophysiological studies have revealed heterogeneous localizations of TRPV1 channels in the airways and their presence in pleural afferents. TRPV1 channels in afferents are not only involved with sensory inputs, but also release several neuropeptides upon stimulation. These processes trigger pathophysiological effects (e.g. reflex bronchoconstriction, hypersecretion, cough, etc.) that cause various symptoms of airway diseases. Recent studies have identified several endogenous and exogenous substances that can activate TRPV1 in the lung. Because of its key role in initiating inflammatory processes, TRPV1 receptor antagonists have been proposed as therapeutic candidates. Therefore, a critical update of recent therapeutic results is also given in this review.
\end{abstract}

Key words: Neurogenic inflammation, bronchoconstriction, mucus secretion, cough, apoptosis, therapy 


\section{Introduction}

Non-myelinated (C-) fibers represent the majority of vagal afferents that innervate the airways and lungs [1]. The afferent activity arising from C-fiber endings plays an important role in regulating respiratory functions under both normal and pathophysiologic conditions. Capsaicin, a pungent ingredient of chili peppers, is known to activate airway C-fibers, and this activation has long been associated with the initiation of several central reflexes, including increases in respiratory rate, parasympathetic bronchoconstriction, mucus hypersecretion, vasodilation, as well as urge to cough sensations and sensations of dyspnea [2, 3].

Recent immunohistochemical studies have revealed the presence of nerve endings, presumably $C$ fibers, that contain tachykinins, such as substance $P(S P)$ and neurokinin $A(N K A)$, and calcitonin gene-related peptide (CGRP) in the airway mucosa [4, 5]. In many species, including humans, these neuropeptides are synthesized in the cell bodies of airway neurons of the trigeminal, jugular and nodose ganglia, and are then transported to and stored in the peripheral endings. The neuropeptides that are released locally from C-fiber endings upon stimulation play important roles in the human respiratory system. They have potent effects on the tone of airway smooth muscle, airway secretions, edema of airway mucosa and on inflammatory and immune cells that mediate neurogenic inflammation via binding tachykinin ligands $\left(\mathrm{NK}_{1}, \mathrm{NK}_{2}\right.$ and $\left.\mathrm{NK}_{3}\right)$ or CGRP receptors [6-14]. Thus, responses evoked by activating $\mathrm{C}$-fiber afferents are mediated both by central reflex pathways and by local or axon reflexes involving the release of tachykinins from sensory endings.

Transient receptor potential vanilloid (TRPV) 1 is a multi-modal, non-selective 
cation channel with a high permeability to $\mathrm{Ca}^{2+}[15,16]$. In the respiratory system, TRPV1 is predominantly found in afferent sensory neurons. It has been hypothesized that TRPV1, together with tachykinin, is responsible for the release of neuropeptides from the sensory terminals, thereby initiating local neurogenic inflammation [14]. To clarify the roles of TRPV1, experiments using selective receptor antagonists and targeted gene deletions in mice have demonstrated the important roles of TRPV channels, particularly TRPV1 in the regulation of airway function [17, 18]. This review will outline our current knowledge of TRPV1 and its potential roles for respiratory medicine.

\section{TRPVs: A brief overview}

Studies with Drosophila opened the door to understanding the roles of transient receptor potential (TRP) channels. The term TRP derives from a transient, rapid decline of electrical potential in photoreceptor cells of mutant Drosophila following prolonged stimulation with light $[19,20]$. To date, 28 ion channels have been identified for the TRP family, which are classified in six subfamilies based on their homologies and activation characteristics. All TRP channels are comprised of six transmembrane domains that assemble as tetramers to form cation-permeable pores. Upon adequate stimulation, the channel opens and allows ions to pass through. Only a small conformational change in the TRP channel protein is required for pore opening, which allows $>10^{6}$ ions per second to flow through each channel and initiate a nerve impulse [15, 16] (Fig 1 Ref [16]).

In mammals, TRP channels are ancient sensory receptors that are ubiquitously expressed in tissues and organs. Not only are they involved in the classical sensory 
transduction processes of multicellular organisms, such as vision, olfaction, taste, thermosensation and other stimuli, but they are also engaged at the single cell level [15]. One TRP subfamily, the transient receptor potential vanilloid subtype (TRPV), consists of six non-specific cation channel receptors [21-23]. The best known member of this family is TRPV1, initially called vanilloid receptor (VR)1. Caterina and co-workers cloned TRPV1 from a rat sensory neuron cDNA library and showed that the receptor is expressed in both the dorsal root (DRG) and trigeminal ganglia (TG) [24]. TRPV1 has also been cloned from humans [25], guinea pigs [26], rabbits [27], mouse mice [28] and dogs [29].

\section{Expression of TRPV-1 in the respiratory system}

Several immunohistochemical studies have described the distributions of TRPV1 within the central nervous system [30], skin [31], gastrointestinal tract [32] and nasal mucosa [33]. Much is known about the mapping of TRPV1 receptors in the animal lung. Recently, an investigation using immunofluorescence and confocal microscopy found a unique distribution and co-localization of TRPV1 and two neuropeptides (CGRP, substance $P$ ) in the extra- and intrapulmonary airways of guinea pigs.

TRPV1 positive axons represented only a small fraction of the total number of PGP9.5 staining nerves within the tracheal epithelium of the guinea pig, and only half of the TRPV1 positive axons also stained positive for substance P. In the intrapulmonary airways, most TRPV1 positive neurons co-localized with substance P and CGRP within and beneath the epithelium, around blood vessels, within airway smooth muscles and alveoli. TRPV1 is predominantly found in sensory nerves that contain neuropeptides, and it is heterogeneously expressed in the airways of guinea pigs $[34,35]$.

TRPV1 expression in the lung is not confined to sensory nerves, as this receptor is 
also present in immortalized human bronchial epithelial cells [36-38], airway smooth muscle cells [35] and mast cells [39]. Recently, parietal pleura afferents were found in the intercostal nerves of rabbits, and these myelinated and unmyelinated fibers had multi-modal properties [40]. In addition, a very recent study demonstrated the presence of acid-sensitive channels, TRPV1 and acid sensing ion channel-3 (ASIC3) in rat DRG neurons projecting to the pleura.

Groth et al. investigated to what extent they were expressed by rat DRG neurons projecting to the lung and pleura using retrograde labelling with antisera against TRPV1, ASIC3 and neurofilament 68 (marker for myelinated neurons) injected into the lung or applied to the costal pleura. It was found that $22 \%$ of pulmonary spinal afferents expressed neither TRPV1 nor ASCI3 channel-immunoreactivity. In contrast, only $3 \%$ of pleural afferents expressed neither TRPV1 nor ASCI3. TRPV $1^{+} / \mathrm{ASIC}^{-}$ neurons with slow conduction velocity (small soma, neurofilament 68-negative) were significantly more frequent among pleural (35\%) than pulmonary afferents $(20 \%)$. $\mathrm{TRPV}^{-} / \mathrm{ASIC}^{+}$neurons were found in between $44 \%$ (lung) and $48 \%$ (pleura) of the neurons, and half of these presumably conducted in the A-fibre range (large soma, neurofilament 68-positive) [41].

In contrast to animal tissue or cultured cells, much less is known about the mapping of TRPV1 receptors in the human lung. One study showed specific staining of nerve profiles for TRPV1 in the subepithelial and epithelial layers in human bronchial tissue obtained by fiberoptic bronchoscopy, but there was little evidence of TRPV1 expression in non-sensory nerve sites [42].

\section{Activation of TRPV1 in the lung}

TRPV1 in the lung may be experimentally activated by a variety of stimuli, such as 
electrical stimulation of the vagus nerve, mechanical stimuli or chemical irritants. Capsaicin is a potent, selective stimulus for the TRPV1 channel. TRPV1 is also activated by acid [43-45], heat [24], arachidoynlethanolamide (AFA and anandamide) $[46,47]$ and the lipoxygenase metabolites of arachidonic acid, including leukotriene B4 (LTB4), 12- and 15-(S)-hydroperoxyeicosatetraenoic acid [12-(S)-HPETE), 15(S)-HPETE] and 5- and 15-(S)-hydroxyeicosatetraenoic acids [5-(S)-HETE), 15-(S)HETE] [48].

In addition to exogenous stimuli, TRPV1 is sensitized by a number of endogenous inflammatory mediators. TRPV1 has several consensus phosphorylation sites where phosphorylation by protein kinases $A, C$ and $G$ (PKA,C and $G$ ) or tyrosine kinase might take place [49-51]. Also, adenosine 5-triphosphate (ATP) and bradykinin enhance TRPV1 activity through a PKC-dependent pathway (See ref. [52] for details on each TRPV1 activator and modulator).

\section{Role of TRPV1 in the respiratory tract under pathophysiological conditions}

\section{Thermal sensing}

The body temperatures of mammalian species are usually maintained within relatively narrow physiological ranges. However, hyperthermia can occur under various conditions. For example, body core temperature can exceed $41^{\circ} \mathrm{C}$ during strenuous exercise, such as marathon running, or in some pathological cases with severe fever $[53,54]$. TRPV channel subtypes play important roles in thermal sensing. In mammals, six thermosensitive ion channels have been reported, all of which belong to the TRP subfamily. The TRPV1, TRPV2, TRPV3 and TRPV4 channel subtypes are the primary thermal sensors, and each TRPV subtype is activated in a different temperature range [22]. TRPV1 exhibits general sensitivity to 
extreme temperatures over $43^{\circ} \mathrm{C}$, which are painful to humans $[24,55]$. However, TRPV1 may be activated at even lower temperatures within the normal physiological range.

The temperature threshold for TRPV1 stimulation is lowered by anandamide or ATP through a PKC-dependent pathway $[50,51]$. A recent study by $\mathrm{Ni}$ et al. showed that isolated rat vagal pulmonary sensory neurons can be directly activated by increases in temperature $\left(35^{\circ} \mathrm{C}\right.$ to $\left.41^{\circ} \mathrm{C}\right)$ as demonstrated by the evoked inward currents. Stimulation was only partially attenuated by pre-treatment with capsazepine or AMG9810, which are selective TRPV1 antagonists. In contrast, after treatment with ruthenium red, a blocker of TRPV1-4 channels, activity was almost completely abolished. In addition, TRPV1-4 channel mRNA and protein expression was evident in these neurons. This indicates that TRPV1, as well as other thermo- sensitive TRPV channel subtypes, are activated within the normal physiological range and play a primary role in regulating the response of pulmonary sensory neurons to hyperthermia [56]. However, the relative contributions of these different TRPV channel subtypes to the thermal sensitivity of these neurons remain to be determined, and the effects of these neurons' activation under normal or pathophysiological condition await future studies.

\section{Acid sensing}

Acidification of pulmonary tissue can commonly occur due to excessive $\mathrm{CO}_{2}$ production (e.g., exercise), impaired $\mathrm{CO}_{2}$ clearance from the lungs (e.g., COPD) [57, 58] or excessive lactic acid production caused by tissue ischemia or hypoxia [59]. In asthmatic patients with acute exacerbations, the $\mathrm{pH}$ of exhaled breath condensates is reduced to 5.23 , as compared to 7.65 in healthy subjects [60]. Low $\mathrm{pH}$ in the 
exhaled breath condensate, which reflects the lining fluid $\mathrm{pH}$ of the lower airways, has been found in various respiratory diseases, such as obstructive sleep apnea [61], chronic cough [62], cystic fibrosis [63], a acute lung injury [64].

Airway acidification induces the release of neuropeptides from bronchopulmonary C fibers $[65,66]$. Two well-established mechanisms for activation of sensory nerves by acid are TRPV1 and ASICs. The airway C-fiber response to acid has both transient and sustained components. Electrophysiological and pharmacological studies show that the TRPV1-mediated response to acid is sustained, while most of the ASIC-type receptors mediate brief transient responses [45, 67].

The transient component is inhibited in a dose-dependent manner by the ASIC blocker amiloride, whereas the sustained component is attenuated, but not abolished by selective TRPV1 antagonism. In addition, there appear to be no interactions between these two chemicals when simultaneously applied to neurons $[65,68]$. In an experiment using TRPV1 knock-out mice, the fact that sustained activation of Cfibers was evoked by acid suggested that ion channels other than TRPV1 can also generate potentials in $\mathrm{C}$-fibers in response to decreases in tissue $\mathrm{pH}$. Little is known regarding the mechanism for the TRPV1-independent response to acid in pulmonary C-fibers. But, numerous acid-sensitive ion channels may contribute to this response, such as TRPV4 [69] and certain types of voltage-gated potassium channels [70].

There is little available information regarding acid-sensing channels in the pleura. Rat pleural afferents express at least two different acid-sensitive channels, TRPV1 and $\mathrm{ASIC} 3$, with a higher prevalence of $\mathrm{TRPV}^{+}{ }^{+} / \mathrm{ASIC}^{-}$neurons among pleural afferents compared to pulmonary afferents. Different expression patterns of these acid sensing channels may make them suitable to monitor tissue acidification. A higher incidence of the TRPV $1^{+} / \mathrm{ASIC}^{-}$pattern might reflect the high sensitivity of 
the parietal pleura to sustained, painful stimuli. However, direct experiments regarding the specific function of this neuron subclass remain to be done [41].

\section{Airway smooth muscle constriction}

Bronchoconstriction is a clinically important feature resulting from neurogenic inflammation. Atropine-resistant bronchoconstriction has been shown in guinea pig airways. It is completely blocked by the simultaneous administration of $\mathrm{NK}_{1}$ and $\mathrm{NK}_{2}$ receptor antagonists both in vitro [71, 72] and in vivo [73]. Tachykinins cause bronchoconstriction through $\mathrm{NK}_{2}$ receptors, and to a lesser extent $\mathrm{NK}_{1}$ receptors, in the guinea pig [74]. In allergic animal models, pre-treatment with capsaicin, which degenerates the airway TRPV1-expressing afferents and depletes sensory neuropeptides, inhibits allergen-induced bronchoconstriction in sensitized guinea pigs [75]. These effects are ascribable to non-cholinergic bronchoconstriction via activation of TRPV1. An analogous non-cholinergic bronchoconstriction has not been consistently demonstrated in humans.

Tachykinergic innervation is absent, or very sparse, around human airway muscle [76]. Electrical field stimulation of human isolated bronchi leads to cholinergic contractions, but not to tachykinergic contractions [77]. A few studies found a small contraction of human bronchi to capsaicin, but a direct role for tachykinins was not investigated $[78,79]$. Other studies have shown that capsaicin either does not contract human bronchial tissue or only causes contractions at non-selective concentrations by mechanisms that do not involve neurokinin receptors [80, 81].

Recently, functional TRPV4 channels in human airway smooth muscle cells have been reported. Jia and co-workers showed a hypotonicity-induced airway contraction that was independent of tachykinin-containing sensory nerves in isolated intact human and guinea pig airways [82]. From their work, a direct action on airway 
smooth muscle via TRPV4 excitation followed by $\mathrm{Ca}^{2+}$ influx may be suggested. TRPV1 channels were unlikely to have been involved in the $\mathrm{Ca}^{2+}$ response in cultured human smooth muscle cells, as TRPV1 mRNA was not expressed and a TRPV1 agonist and an antagonist had no effects on $\mathrm{Ca}^{2+}$ influx. However, a recent study showed that TRPV1 is up-regulated in airway smooth muscle in patients with chronic cough [83]. Whether or not the direct action via TRPV1 excitation on airway smooth muscle applies to pathological conditions in human airways, such as asthma or COPD, remains to be determined.

\section{Cough}

Several studies support a linkage between TRPV1 and cough. Inhalation of the well-known TRPV1 agonist capsaicin consistently and reproducibly elicits cough in animals and humans [84-86]. TRPV1 receptors are found on sensory airway nerves that play important roles in the cough reflex $[13,42,52,87]$. Groneberg et al. found a significant correlation between the capsaicin tussive response and the numbers of TRPV1 positive nerves in patients with chronic cough of diverse causes, suggesting that TRPV1 receptors contributed to the enhanced cough reflex [42].

In some studies, TRPV1 antagonists inhibited coughs elicited by capsaicin and citric acid in guinea pigs $[88,89]$ and by aerosol exposure to ovalbumin in sensitised guinea pigs [90]. More direct evidence linking TRPV1 channel activity to airway sensory neurons innervating inflammatory airways was recently provided by McLeod et al. who demonstrated the effects of airway inflammation induced by sulfur dioxide $\left(\mathrm{SO}_{2}\right)$ exposure on TRPV1 receptor activity in vagal sensory neurons and cough. Using a subacute $\mathrm{SO}_{2}$ exposure model in guinea pigs, intracellular $\mathrm{Ca}^{2+}$ responses in nodose ganglia cells evoked by capsaicin were significantly augmented in $\mathrm{SO}_{2}$ exposed animals compared to nodose ganglia from control guinea pigs. This 
response was blocked by the TRPV1 antagonist capsazepine $(1 \mu \mathrm{M})$. In addition, cough responses elicited by aerosolised capsaicin and the numbers of BAL neutrophils were significantly increased in $\mathrm{SO}_{2}$-exposed guinea pigs compared to controls [91]. This study suggests that up-regulated TRPV1 may play an important role in cough under inflammatory conditions.

\section{Mucus secretion}

Chronic mucus hypersecretion is indicative of poor asthma control and is an important characteristic of chronic obstructive pulmonary disease (COPD) [92, 93]. Up-regulation of the lung sensory neural pathways has been implicated in asthma and COPD. Tachykinins released from sensory nerves act mainly through $\mathrm{NK}_{1}$ receptors in sensory glands, and mediate mucus hypersecretion, edema, vasodilatation and the release of pro-inflammatory cytokines [94, 95]. Preprotachykinin (PPT)-A, a precursor of SP, NKA and $\mathrm{NK}_{1}$, is expressed at high levels in human COPD airway extracts. $\mathrm{NK}_{1}$ protein, PPT-A mRNA and SP protein are even more abundantly expressed in human COPD airway tissue [96].

A recent in vivo study found evidence of a role for TRPV1 in mucus secretion in capsaicin-evoked airway inflammation of rats. Karmouty-Quintana et al. showed that the TRPV1 antagonist capsazepine completely inhibited the fluid signals detected by magnetic resonance imaging and reduced mucin levels in BAL fluid induced by capsaicin. Furthermore, pre-treatment with a dual NK1/NK2 receptor antagonist completely inhibited the mucus release induced by capsaicin [97]. Taken together, these results suggest that the activation of TRPV1 may promote the release of tachykinins, $\mathrm{SP}$ and $\mathrm{NKA}$, resulting in mucus secretion through $\mathrm{NK}_{1}$ and/or $\mathrm{NK}_{2}$ receptors.

\section{Apoptosis and TRPV1}


In vitro studies using human bronchial epithelial cells have demonstrated increased production of pro-inflammatory cytokines, such as interleukin-6 and interleukin-8, and oncotic cell death associated with TRPV1 activation [37, 98]. Other studies have also demonstrated that particulate matter increases intracellular $\mathrm{Ca}^{2+}$ and induces apoptosis of cultured lung epithelial cells via activation of TRPV1 [38, 99]. These results indicate that TRPV1 is a mediator of lung injury and inflammation. However, the detailed molecular mechanisms associated with cell death have not been established.

A very recent study addressed the effects of TRPV1 on the endoplasmic reticulum (ER) regarding stress and cell death in human bronchial epithelium and alveolar cells [100]. TRPV1 agonist (nonivamide) treatment induced calcium release from the ER and changed the transcription of growth arrest- and DNA damage-inducible transcript 3 (GADD153, GADD45alpha, GRP78/BiP, ATF3, CCND1 and CCNG2) in a manner similar to prototypical ER stress-inducing agents. Also, the TRPV1 antagonist N-(4tert-butylbenzyl)-N'-(1-[3-fluoro-4-(methylsulfonylamino)-phenyl]ethyl) thiourea (LJO328) inhibited mRNA responses and cytotoxicity. These results indicated that TRPV1 activation caused cell death and tissue damage via the ER stress pathway, and provided novel insights into the mechanisms of how exogenous and/or endogenous TRPV1 agonists may affect lung cell pathophysiology.

\section{Protective role of TRPV1}

Several studies support the notion that activated TRPV1 elicits inflammation and cell injury in lung epithelial cells. Accordingly, inhibition of TRPV1 receptors has potential benefits to prevent certain pathological actions and toxicity [101]. However, more recently, counter-regulatory functions of TRPV1 have been described in an endotoxin-induced sepsis model in the TRPV1 knock-out mouse. In TRPV1 knock- 
out mice after intraperitoneal injection of lipopolysaccharide (LPS), Clark et al. demonstrated enhanced hypotension, hypothermia and mediator levels in peritoneal exudates, which indicated a loss of protective effects [99]. Helyes et al. also investigated the role of TRPV1 in endotoxin-induced airway inflammation and subsequent bronchial hyperreactivity in TRPV1 knock-out mice using intranasal LPS administration. They showed that bronchial hyperreactivity, inflammatory indices (edema, inflammatory cell infiltration, goblet cell hyperplasia in airway) and myeloperoxidase activity were significantly greater in TRPV1 knock-out mice compared to wild type mice. Furthermore, these results were attenuated by the exogenous administration of somatostatin in TRPV1 knock-out mice [102]. Several studies have shown that somatostatin released from capsaicin-sensitive sensory nerve terminals reaches the circulation and elicits systemic anti-inflammatory effects [103-105].

\section{Targeting TRPV 1 in the treatment of airway disease}

Based on evidence suggesting that TRPV1 is a mediator for many lung pathologies caused by toxicants and endogenous agonists, and due to its central role in neurogenic inflammation, TRPV1 might be a good target for pharmacological intervention for pain, inflammation and preventing lung disorders $[106,107]$. TRPV1 antagonists are under intense investigation in several animal models. Some preclinical studies suggest that TRPV1 antagonists may be useful as novel analgesic drugs, and may also be effective for bladder hyperactivity [106].

Chizh et al. reported the potential analgesic utility of the TRPV1 antagonist SB705498 in men. They showed that orally administrated SB-705498 significantly reduced the area of capsaicin-evoked flare and elevated the heat pain threshold without any serious adverse events [104]. However, a more recent study revealed 
that systemic use of the TRPV1 blockade AMG 517 elicited undesirable hyperthermia in susceptible individuals, which may limit its therapeutic use [108]. Also, AMG 517 has a long half-life in humans (13-23 days) [109]. Although the body temperature effects of TRPV1 blockade with a short half-life remain to be determined in humans, a short half-life compound may be more suited for clinical use. Or, there might be a place for anatomically-restricted administration of TRPV1 antagonists, either topically or by injection, that would prevent access to thermoregulatory visceral afferents [109, 110].

In respiratory medicine, pulmonologists have developed an interest in the possible role of the TRPV1 channel in respiratory diseases [111]. TRPV1 antagonists have potential indications for respiratory conditions, such as asthma, COPD and chronic cough [52]. However, a recent study showed the potential negative effects for therapeutic uses of TRPV1 antagonists in the lung. Johansen et al. found that prolonged treatment of BEAS-2B human bronchial epithelial cells with TRPV1 antagonists (LJO-328, SC0030 or capsazepine) for 24 hours significantly increased $\mathrm{Ca}^{2+}$ flux and cytokine gene expression (IL-6, IL-8), and cells exhibited greater cytotoxicity in response to the TRPV1 agonist nonivamide compared to cells that were not pre-treated with antagonists. However, TRPV1 mRNA levels in pre-treated cells showed no increase, and sensitisation was attenuated by brefeldin A (a Golgi transport inhibitor), but not by cycloheximide (a protein synthesis inhibitor) or by actinomycin D (a transcription inhibitor). These results suggest that the observed sensitisation of TRPV1 receptors by pre-treatment with a TRPV1 antagonist was probably due to an increased number of expressed receptors, which resulted from the translocation of existing receptors from the endoplasmic reticulum to the cell surface [112]. These results may add to our understanding of TRPV1 sensitization. 
However, a previous study showed that expression of TRPV1 on epithelial cells was rare $(<1 \%$ of epithelial cells) in patients with cough [42], and there is no evidence that such a sensitization occurs for sensory nerves. Whether this phenomenon applies to other tissues or under in vivo conditions is unclear, but it warrants examination [113].

\section{Conclusion}

TRPs are ubiquitously expressed in tissues and organs, and they sense a diverse range of stimuli. TRPs are thought to play roles as intrinsic sensors of the cellular environment under normal and pathophysiological conditions. The cloning of TRPV1 in the last decade engendered a large amount of evidence that neurogenic inflammation may play an important role in the pathophysiology of pulmonary disease. Furthermore, it has stimulated studies revealing the roles for TRPV1 in respiratory medicine. Experiments that used selective receptor antagonists and targeted gene inactivation in mice have begun to reveal the essential mechanisms of TRPV channels. Still, however, only little is known regarding the precise role for TRPV1, especially in human airway diseases such as asthma or COPD. Ultimately, a better understanding of the mechanisms underlying TRPV1 activation and sensitisation will lead to the development of novel therapeutic strategies in the treatment of inflammatory diseases of the lung.

\section{Conflict of interest}

The authors declare no conflict of interest. 


\section{References}

[1] Agostoni E, Chinnock JE, De Daly MB, Murray JG. Functional and histological studies of the vagus nerve and its branches to the heart, lungs and abdominal viscera in the cat. J Physiol 1957;135:182-205.

[2] Coleridge JC, Coleridge HM. Afferent vagal $C$ fibre innervation of the lungs and airways and its functional significance. Rev Physiol Biochem Pharmacol 1984;99:1-110.

[3] Lee LY, Pisarri TE. Afferent properties and reflex functions of bronchopulmonary C-fibers. Respir Physiol 2001;125:47-65.

[4] Baluk P, Nadel JA, McDonald DM. Substance P-immunoreactive sensory axons in the rat respiratory tract: a quantitative study of their distribution and role in neurogenic inflammation. J Comp Neurol 1992;319:586-598.

[5] Adriaensen D, Timmermans JP, Brouns I, Berthoud HR, Neuhuber WL, Scheuermann DW. Pulmonary intraepithelial vagal nodose afferent nerve terminals are confined to neuroepithelial bodies: an anterograde tracing and confocal microscopy study in adult rats. Cell Tissue Res 1998;293:395-405.

[6] Lembeck F, Holzer P. Substance $P$ as neurogenic mediator of antidromic vasodilation and neurogenic plasma extravasation. Naunyn Schmiedebergs Arch Pharmacol 1979;310:175-183.

[7] Lundberg JM, Saria A. Polypeptide-containing neurons in airway smooth muscle. Annu Rev Physiol 1987;49:557-572.

[8] Solway J, Leff AR. Sensory neuropeptides and airway function. J Appl Physiol $1991 ; 71: 2077-2087$.

[9] Joos GF, Germonpre PR, Pauwels RA. Role of tachykinins in asthma. Allergy 2000;55:321-337. 
[10] Barnes PJ. Neurogenic inflammation in the airways. Respir Physiol 2001;125:145-154.

[11] Groneberg DA, Quarcoo D, Frossard N, Fischer A. Neurogenic mechanisms in bronchial inflammatory diseases. Allergy 2004;59:1139-1152.

[12] Dinh QT, Mingomataj E, Quarcoo D, Groneberg DA, Witt C, Klapp BF, Braun A, Fischer A. Allergic airway inflammation induces tachykinin peptides expression in vagal sensory neurons innervating mouse airways. Clin Exp Allergy 2005;35:820-825. [13] De Swert KO, Joos GF. Extending the understanding of sensory neuropeptides. Eur J Pharmacol 2006;533:171-181.

[14] Geppetti P, Materazzi S, Nicoletti P. The transient receptor potential vanilloid 1: role in airway inflammation and disease. Eur J Pharmacol 2006;533:207-214.

[15] Clapham DE. TRP channels as cellular sensors. Nature 2003;426:517-524.

[16] Tominaga M, Tominaga T. Structure and function of TRPV1. Pflugers Arch 2005;451:143-150.

[17] Szallasi A. Small molecule vanilloid TRPV1 receptor antagonists approaching drug status: can they live up to the expectations? Naunyn Schmiedebergs Arch Pharmacol 2006;373:273-286.

[18] Davis JB, Gray J, Gunthorpe MJ, Hatcher JP, Davey PT, Overend P, Harries MH, Latcham J, Clapham C, Atkinson K, Hughes SA, Rance K, Grau E, Harper AJ, Pugh PL, Rogers DC, Bingham S, Randall A, Sheardown SA. Vanilloid receptor-1 is essential for inflammatory thermal hyperalgesia. Nature 2000;405:183-187.

[19] Minke B. Drosophila mutant with a transducer defect. Biophys Struct Mech $1977 ; 3: 59-64$.

[20] Montell C, Jones K, Hafen E, Rubin G. Rescue of the Drosophila phototransduction mutation trp by germline transformation. Science 1985;230:10401043. 
[21] Montell C, Birnbaumer L, Flockerzi V. The TRP channels, a remarkably functional family. Cell 2002;108:595-598.

[22] Benham CD, Gunthorpe MJ, Davis JB. TRPV channels as temperature sensors. Cell Calcium 2003;33:479-487.

[23] Nilius B, Vriens J, Prenen J, Droogmans G, Voets T. TRPV4 calcium entry channel: a paradigm for gating diversity. Am J Physiol Cell Physiol 2004;286:C195205.

[24] Caterina MJ, Schumacher MA, Tominaga M, Rosen TA, Levine JD, Julius D. The capsaicin receptor: a heat-activated ion channel in the pain pathway. Nature 1997;389:816-824.

[25] Hayes P, Meadows HJ, Gunthorpe MJ, Harries MH, Duckworth DM, Cairns W, Harrison DC, Clarke CE, Ellington K, Prinjha RK, Barton AJ, Medhurst AD, Smith GD, Topp S, Murdock P, Sanger GJ, Terrett J, Jenkins O, Benham CD, Randall AD, Gloger IS, Davis JB. Cloning and functional expression of a human orthologue of rat vanilloid receptor-1. Pain 2000;88:205-215.

[26] Savidge J, Davis C, Shah K, Colley S, Phillips E, Ranasinghe S, Winter J, Kotsonis $\mathrm{P}$, Rang $\mathrm{H}$, Mclntyre $\mathrm{P}$. Cloning and functional characterization of the guinea pig vanilloid receptor 1. Neuropharmacology 2002;43:450-456.

[27] Gavva NR, Klionsky L, Qu Y, Shi L, Tamir R, Edenson S, Zhang TJ, Viswanadhan VN, Toth A, Pearce LV, Vanderah TW, Porreca F, Blumberg PM, Lile J, Sun Y, Wild K, Louis JC, Treanor JJ. Molecular determinants of vanilloid sensitivity in TRPV1. J Biol Chem 2004;279:20283-20295.

[28] Correll CC, Phelps PT, Anthes JC, Umland S, Greenfeder S. Cloning and pharmacological characterization of mouse TRPV1. Neurosci Lett 2004;370:55-60.

[29] Phelps PT, Anthes JC, Correll CC. Cloning and functional characterization of dog transient receptor potential vanilloid receptor-1 (TRPV1). Eur J Pharmacol 
2005;513:57-66.

[30] Mezey E, Toth ZE, Cortright DN, Arzubi MK, Krause JE, Elde R, Guo A, Blumberg PM, Szallasi A. Distribution of mRNA for vanilloid receptor subtype 1 (VR1), and VR1-like immunoreactivity, in the central nervous system of the rat and human. Proc Natl Acad Sci U S A 2000;97:3655-3660.

[31] Guo A, Vulchanova L, Wang J, Li X, Elde R. Immunocytochemical localization of the vanilloid receptor 1 (VR1): relationship to neuropeptides, the P2X3 purinoceptor and IB4 binding sites. Eur J Neurosci 1999;11:946-958.

[32] Patterson LM, Zheng H, Ward SM, Berthoud HR. Vanilloid receptor (VR1) expression in vagal afferent neurons innervating the gastrointestinal tract. Cell Tissue Res 2003;311:277-287.

[33] Taylor-Clark TE, Kollarik M, MacGlashan DW, Jr., Undem BJ. Nasal sensory nerve populations responding to histamine and capsaicin. J Allergy Clin Immunol 2005;116:1282-1288.

[34] Watanabe N, Horie S, Michael GJ, Spina D, Page CP, Priestley JV. Immunohistochemical localization of vanilloid receptor subtype 1 (TRPV1) in the guinea pig respiratory system. Pulm Pharmacol Ther 2005;18:187-197.

[35] Watanabe N, Horie S, Michael GJ, Keir S, Spina D, Page CP, Priestley JV. Immunohistochemical co-localization of transient receptor potential vanilloid (TRPV)1 and sensory neuropeptides in the guinea-pig respiratory system. Neuroscience 2006;141:1533-1543.

[36] Veronesi B, Oortgiesen M, Carter JD, Devlin RB. Particulate matter initiates inflammatory cytokine release by activation of capsaicin and acid receptors in a human bronchial epithelial cell line. Toxicol Appl Pharmacol 1999;154:106-115.

[37] Reilly CA, Taylor JL, Lanza DL, Carr BA, Crouch DJ, Yost GS. Capsaicinoids cause inflammation and epithelial cell death through activation of vanilloid receptors. 
Toxicol Sci 2003;73:170-181.

[38] Agopyan N, Head J, Yu S, Simon SA. TRPV1 receptors mediate particulate matter-induced apoptosis. Am J Physiol Lung Cell Mol Physiol 2004;286:L563-572.

[39] Biro T, Maurer M, Modarres S, Lewin NE, Brodie C, Acs G, Acs P, Paus R, Blumberg PM. Characterization of functional vanilloid receptors expressed by mast cells. Blood 1998;91:1332-1340.

[40] Jammes Y, Trousse D, Delpierre S. Identification and properties of parietal pleural afferents in rabbits. J Physiol 2005;567:641-650.

[41] Groth M, Helbig T, Grau V, Kummer W, Haberberger RV. Spinal afferent neurons projecting to the rat lung and pleura express acid sensitive channels. Respir Res 2006;7:96.

[42] Groneberg DA, Niimi A, Dinh QT, Cosio B, Hew M, Fischer A, Chung KF. Increased expression of transient receptor potential vanilloid-1 in airway nerves of chronic cough. Am J Respir Crit Care Med 2004;170:1276-1280.

[43] Geppetti P, Del Bianco E, Patacchini R, Santicioli P, Maggi CA, Tramontana M. Low $\mathrm{pH}$-induced release of calcitonin gene-related peptide from capsaicin-sensitive sensory nerves: mechanism of action and biological response. Neuroscience $1991 ; 41: 295-301$.

[44] Bevan S, Geppetti P. Protons: small stimulants of capsaicin-sensitive sensory nerves. Trends Neurosci 1994;17:509-512.

[45] Tominaga M, Caterina MJ, Malmberg AB, Rosen TA, Gilbert H, Skinner K, Raumann BE, Basbaum Al, Julius D. The cloned capsaicin receptor integrates multiple pain-producing stimuli. Neuron 1998;21:531-543.

[46] Zygmunt PM, Petersson J, Andersson DA, Chuang H, Sorgard M, Di Marzo V, Julius D, Hogestatt ED. Vanilloid receptors on sensory nerves mediate the vasodilator action of anandamide. Nature 1999;400:452-457. 
[47] Kollarik M, Undem BJ. Activation of bronchopulmonary vagal afferent nerves with bradykinin, acid and vanilloid receptor agonists in wild-type and TRPV1-/- mice. J Physiol 2004;555:115-123.

[48] Hwang SW, Cho H, Kwak J, Lee SY, Kang CJ, Jung J, Cho S, Min KH, Suh YG, Kim D, Oh U. Direct activation of capsaicin receptors by products of lipoxygenases: endogenous capsaicin-like substances. Proc Natl Acad Sci U S A 2000;97:6155-6160.

[49] Gu Q, Kwong K, Lee LY. Ca2+ transient evoked by chemical stimulation is enhanced by PGE2 in vagal sensory neurons: role of cAMP/PKA signaling pathway. J Neurophysiol 2003;89:1985-1993.

[50] Premkumar LS, Ahern GP. Induction of vanilloid receptor channel activity by protein kinase C. Nature 2000;408:985-990.

[51] Vellani V, Mapplebeck S, Moriondo A, Davis JB, McNaughton PA. Protein kinase $\mathrm{C}$ activation potentiates gating of the vanilloid receptor VR1 by capsaicin, protons, heat and anandamide. J Physiol 2001;534:813-825.

[52] Jia Y, Lee LY. Role of TRPV receptors in respiratory diseases. Biochim Biophys Acta 2007;1772:915-927.

[53] Brooks GA, Hittelman KJ, Faulkner JA, Beyer RE. Tissue temperatures and whole-animal oxygen consumption after exercise. Am J Physiol 1971;221:427-431.

[54] Maron MB, Wagner JA, Horvath SM. Thermoregulatory responses during competitive marathon running. J Appl Physiol 1977;42:909-914.

[55] Tominaga M, Caterina MJ. Thermosensation and pain. J Neurobiol 2004;61:312.

[56] Ni D, Gu Q, Hu HZ, Gao N, Zhu MX, Lee LY. Thermal sensitivity of isolated vagal pulmonary sensory neurons: role of transient receptor potential vanilloid receptors. Am J Physiol Regul Integr Comp Physiol 2006;291:R541-550. 
[57] Berger KI, Ayappa I, Sorkin IB, Norman RG, Rapoport DM, Goldring RM. $\mathrm{CO}(2)$ homeostasis during periodic breathing in obstructive sleep apnea. J Appl Physiol 2000;88:257-264.

[58] Wasserman K, Whipp BJ, Casaburi R, Beaver WL. Carbon dioxide flow and exercise hyperpnea. Cause and effect. Am Rev Respir Dis 1977;115:225-237.

[59] Rotto DM, Kaufman MP. Effect of metabolic products of muscular contraction on discharge of group III and IV afferents. J Appl Physiol 1988;64:2306-2313.

[60] Hunt JF, Fang K, Malik R, Snyder A, Malhotra N, Platts-Mills TA, Gaston B. Endogenous airway acidification. Implications for asthma pathophysiology. Am J Respir Crit Care Med 2000;161:694-699.

[61] Petrosyan M, Perraki E, Simoes D, Koutsourelakis I, Vagiakis E, Roussos C, Gratziou C. Exhaled breath markers in patients with obstructive sleep apnoea. Sleep Breath 2008;12:207-215.

[62] Niimi A, Nguyen LT, Usmani O, Mann B, Chung KF. Reduced pH and chloride levels in exhaled breath condensate of patients with chronic cough. Thorax 2004;59:608-612.

[63] Ojoo JC, Mulrennan SA, Kastelik JA, Morice AH, Redington AE. Exhaled breath condensate $\mathrm{pH}$ and exhaled nitric oxide in allergic asthma and in cystic fibrosis. Thorax 2005;60:22-26.

[64] Gessner C, Hammerschmidt S, Kuhn H, Seyfarth HJ, Sack U, Engelmann L, Schauer J, Wirtz H. Exhaled breath condensate acidification in acute lung injury. Respir Med 2003;97:1188-1194.

[65] Kollarik M, Undem BJ. Mechanisms of acid-induced activation of airway afferent nerve fibres in guinea-pig. J Physiol 2002;543:591-600.

[66] Ricciardolo FL. Mechanisms of citric acid-induced bronchoconstriction. Am J Med 2001;111 Suppl 8A:18S-24S. 
[67] Waldmann R, Bassilana F, de Weille J, Champigny G, Heurteaux C, Lazdunski M. Molecular cloning of a non-inactivating proton-gated $\mathrm{Na}+$ channel specific for sensory neurons. J Biol Chem 1997;272:20975-20978.

[68] Gu Q, Lee LY. Characterization of acid signaling in rat vagal pulmonary sensory neurons. Am J Physiol Lung Cell Mol Physiol 2006;291:L58-65.

[69] Suzuki M, Mizuno A, Kodaira K, Imai M. Impaired pressure sensation in mice lacking TRPV4. J Biol Chem 2003;278:22664-22668.

[70] O'Connell AD, Morton MJ, Hunter M. Two-pore domain $\mathrm{K}+$ channelsmolecular sensors. Biochim Biophys Acta 2002;1566:152-161.

[71] Maggi CA, Patacchini R, Rovero P, Santicioli P. Tachykinin receptors and noncholinergic bronchoconstriction in the guinea-pig isolated bronchi. Am Rev Respir Dis $1991 ; 144: 363-367$.

[72] Boni P, Ballati L, Evangelista S. Tachykinin NK1 and NK2 receptors mediate the non-cholinergic bronchospastic response to capsaicin and vagal stimulation in guinea-pigs. J Auton Pharmacol 1995;15:49-54.

[73] Bertrand C, Nadel JA, Graf PD, Geppetti P. Capsaicin increases airflow resistance in guinea pigs in vivo by activating both NK2 and NK1 tachykinin receptors. Am Rev Respir Dis 1993;148:909-914.

[74] Amadesi S, Moreau J, Tognetto M, Springer J, Trevisani M, Naline E, Advenier C, Fisher A, Vinci D, Mapp C, Miotto D, Cavallesco G, Geppetti P. NK1 receptor stimulation causes contraction and inositol phosphate increase in medium-size human isolated bronchi. Am J Respir Crit Care Med 2001;163:1206-1211.

[75] Manzini S, Maggi CA, Geppetti P, Bacciarelli C. Capsaicin desensitization protects from antigen-induced bronchospasm in conscious guinea-pigs. Eur $\mathrm{J}$ Pharmacol 1987;138:307-308.

[76] Luts A, Uddman R, Alm P, Basterra J, Sundler F. Peptide-containing nerve 
fibers in human airways: distribution and coexistence pattern. Int Arch Allergy Immunol 1993;101:52-60.

[77] Lundberg JM, Martling CR, Saria A. Substance P and capsaicin-induced contraction of human bronchi. Acta Physiol Scand 1983;119:49-53.

[78] Honda I, Kohrogi H, Yamaguchi T, Ando M, Araki S. Enkephalinase inhibitor potentiates substance $\mathrm{P}$ - and capsaicin-induced bronchial smooth muscle contractions in humans. Am Rev Respir Dis 1991;143:1416-1418.

[79] Hathaway TJ, Higenbottam TW, Morrison JF, Clelland CA, Wallwork J. Effects of inhaled capsaicin in heart-lung transplant patients and asthmatic subjects. Am Rev Respir Dis 1993;148:1233-1237.

[80] Molimard M, Martin CA, Naline E, Hirsch A, Advenier C. Contractile effects of bradykinin on the isolated human small bronchus. Am J Respir Crit Care Med 1994;149:123-127.

[81] Ellis JL, Sham JS, Undem BJ. Tachykinin-independent effects of capsaicin on smooth muscle in human isolated bronchi. Am J Respir Crit Care Med 1997;155:751755.

[82] Jia Y, Wang X, Varty L, Rizzo CA, Yang R, Correll CC, Phelps PT, Egan RW, Hey JA. Functional TRPV4 channels are expressed in human airway smooth muscle cells. Am J Physiol Lung Cell Mol Physiol 2004;287:L272-278.

[83] Mitchell JE, Campbell AP, New NE, Sadofsky LR, Kastelik JA, Mulrennan SA, Compton SJ, Morice AH. Expression and characterization of the intracellular vanilloid receptor (TRPV1) in bronchi from patients with chronic cough. Exp Lung Res 2005;31:295-306.

[84] Karlsson JA, Fuller RW. Pharmacological regulation of the cough reflex--from experimental models to antitussive effects in Man. Pulm Pharmacol Ther 1999;12:215-228. 
[85] Undem BJ, Chuaychoo B, Lee MG, Weinreich D, Myers AC, Kollarik M. Subtypes of vagal afferent C-fibres in guinea-pig lungs. J Physiol 2004;556:905-917. [86] Dicpinigaitis PV. Experimentally induced cough. Pulm Pharmacol Ther 2007;20:319-324.

[87] Jia Y, McLeod RL, Wang X, Parra LE, Egan RW, Hey JA. Anandamide induces cough in conscious guinea-pigs through VR1 receptors. $\mathrm{Br} \mathrm{J}$ Pharmacol 2002;137:831-836.

[88] Trevisani M, Milan A, Gatti R, Zanasi A, Harrison S, Fontana G, Morice AH, Geppetti P. Antitussive activity of iodo-resiniferatoxin in guinea pigs. Thorax 2004;59:769-772.

[89] Leung SY, Niimi A, Williams AS, Nath P, Blanc FX, Dinh QT, Chung KF. Inhibition of citric acid- and capsaicin-induced cough by novel TRPV-1 antagonist, V112220, in guinea-pig. Cough 2007;3:10.

[90] McLeod RL, Fernandez X, Correll CC, Phelps TP, Jia Y, Wang X, Hey JA. TRPV1 antagonists attenuate antigen-provoked cough in ovalbumin sensitized guinea pigs. Cough 2006;2:10.

[91] McLeod RL, Jia Y, McHugh NA, Fernandez X, Mingo GG, Wang X, Parra LE, Chen J, Brown D, Bolser DC, Kreutner W, Hey JA. Sulfur-dioxide exposure increases TRPV1-mediated responses in nodose ganglia cells and augments cough in guinea pigs. Pulm Pharmacol Ther 2007;20:750-757.

[92] Rogers DF. Airway mucus hypersecretion in asthma: an undervalued pathology? Curr Opin Pharmacol 2004;4:241-250.

[93] Rogers DF. Mucociliary dysfunction in COPD: effect of current pharmacotherapeutic options. Pulm Pharmacol Ther 2005;18:1-8.

[94] Rogers DF. Neurokinin receptors subserving airways secretion. Can J Physiol Pharmacol 1995;73:932-939. 
[95] Reynolds PN, Holmes MD, Scicchitano R. Role of tachykinins in bronchial hyper-responsiveness. Clin Exp Pharmacol Physiol 1997;24:273-280.

[96] Springer J, Groneberg DA, Pregla R, Fischer A. Inflammatory cells as source of tachykinin-induced mucus secretion in chronic bronchitis. Regul Pept 2005;124:195-201.

[97] Karmouty-Quintana H, Cannet C, Sugar R, Fozard JR, Page CP, Beckmann N. Capsaicin-induced mucus secretion in rat airways assessed in vivo and noninvasively by magnetic resonance imaging. $\mathrm{Br} \mathrm{J}$ Pharmacol 2007;150:1022-1030.

[98] Reilly CA, Johansen ME, Lanza DL, Lee J, Lim JO, Yost GS. Calciumdependent and independent mechanisms of capsaicin receptor (TRPV1)-mediated cytokine production and cell death in human bronchial epithelial cells. J Biochem Mol Toxicol 2005;19:266-275.

[99] Clark N, Keeble J, Fernandes ES, Starr A, Liang L, Sugden D, de Winter P, Brain SD. The transient receptor potential vanilloid 1 (TRPV1) receptor protects against the onset of sepsis after endotoxin. FASEB J 2007;21:3747-3755.

[100] Thomas KC, Sabnis AS, Johansen ME, Lanza DL, Moos PJ, Yost GS, Reilly CA. Transient receptor potential vanilloid 1 agonists cause endoplasmic reticulum stress and cell death in human lung cells. J Pharmacol Exp Ther 2007;321:830-838.

[101] Agopyan N, Bhatti T, Yu S, Simon SA. Vanilloid receptor activation by 2- and 10-microm particles induces responses leading to apoptosis in human airway epithelial cells. Toxicol Appl Pharmacol 2003;192:21-35.

[102] Helyes Z, Elekes K, Nemeth J, Pozsgai G, Sandor K, Kereskai L, Borzsei R, Pinter E, Szabo A, Szolcsanyi J. Role of transient receptor potential vanilloid 1 receptors in endotoxin-induced airway inflammation in the mouse. Am J Physiol Lung Cell Mol Physiol 2007;292:L1173-1181.

[103] Szolcsanyi J, Helyes Z, Oroszi G, Nemeth J, Pinter E. Release of 
somatostatin and its role in the mediation of the anti-inflammatory effect induced by antidromic stimulation of sensory fibres of rat sciatic nerve. $\mathrm{Br} \mathrm{J}$ Pharmacol 1998;123:936-942.

[104] Than M, Nemeth J, Szilvassy Z, Pinter E, Helyes Z, Szolcsanyi J. Systemic anti-inflammatory effect of somatostatin released from capsaicin-sensitive vagal and sciatic sensory fibres of the rat and guinea-pig. Eur J Pharmacol 2000;399:251-258. [105] Helyes Z, Pinter E, Nemeth J, Keri G, Than M, Oroszi G, Horvath A, Szolcsanyi J. Anti-inflammatory effect of synthetic somatostatin analogues in the rat. Br J Pharmacol 2001;134:1571-1579.

[106] Jia Y, McLeod RL, Hey JA. TRPV1 receptor: a target for the treatment of pain, cough, airway disease and urinary incontinence. Drug News Perspect 2005;18:165171.

[107] Szallasi A, Cruz F, Geppetti P. TRPV1: a therapeutic target for novel analgesic drugs? Trends Mol Med 2006;12:545-554.

[108] Gavva NR, Treanor JJ, Garami A, Fang L, Surapaneni S, Akrami A, Alvarez F, Bak A, Darling M, Gore A, Jang GR, Kesslak JP, Ni L, Norman MH, Palluconi G, Rose MJ, Salfi M, Tan E, Romanovsky AA, Banfield C, Davar G. Pharmacological blockade of the vanilloid receptor TRPV1 elicits marked hyperthermia in humans. Pain 2008;136:202-210.

[109] Mills C, McMackin M, Jaffe R, Yu J, Zininberg E, Slee D, Gogas K, Bradbury M. Effects of the transient receptor potential vanilloid 1 antagonist A-425619 on body temperature and thermoregulation in the rat. Neuroscience 2008;156:165-174.

[110] Caterina MJ. On the thermoregulatory perils of TRPV1 antagonism. Pain 2008;136:3-4.

[111] Morice $\mathrm{AH}$, Geppetti P. Cough. 5: The type 1 vanilloid receptor: a sensory receptor for cough. Thorax 2004;59:257-258. 
[112] Johansen ME, Reilly CA, Yost GS. TRPV1 antagonists elevate cell surface populations of receptor protein and exacerbate TRPV1-mediated toxicities in human lung epithelial cells. Toxicol Sci 2006;89:278-286.

[113] Veronesi B, Oortgiesen M. The TRPV1 receptor: target of toxicants and therapeutics. Toxicol Sci 2006;89:1-3. 


\section{Figure legend}

Fig. 1 (A) Proposed tetrameric structure of transient receptor potential vanilloid 1 (TRPV1) in the plasma membrane. (B) Single-channel recordings after TRPV1 activation by capsaicin $($ cap, $100 \mathrm{nM})$, heat $\left(44^{\circ} \mathrm{C}\right)$ or protons $(\mathrm{pH} 5.4)$ at $+40 \mathrm{mV}$ for the inside/out (protons) configuration. Broken lines indicate closed channel levels. 
Figure 1:

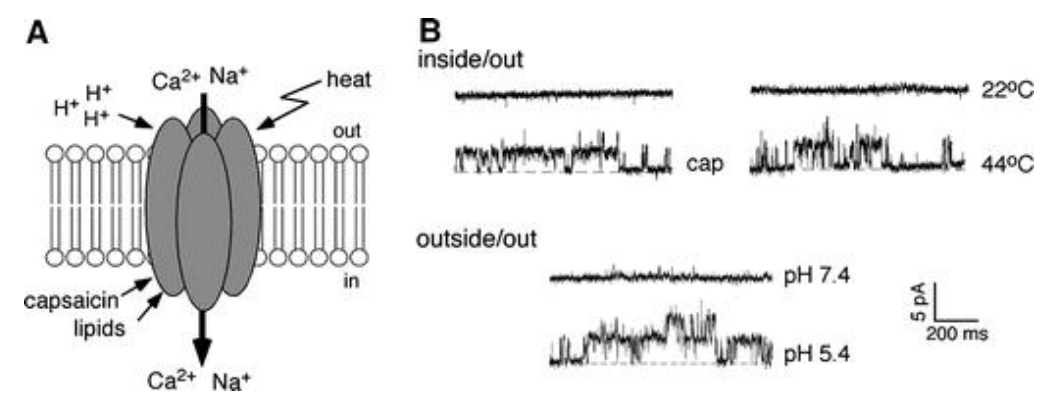

